\title{
Communication
}

\section{Identification of Polymorphisms of the CSN2 Gene Encoding $\beta$-Casein in Greek Local Breeds of Cattle}

\author{
Dionysios Antonopoulos ${ }^{1}$, Despina Vougiouklaki ${ }^{1}$, George P. Laliotis ${ }^{2}$ (D), Theofania Tsironi ${ }^{3}$ (D), Irene Valasi ${ }^{4}$, \\ Archodoula Chatzilazarou ${ }^{5}$, Panagiotis Halvatsiotis ${ }^{6}(\mathbb{D}$ and Dimitra Houhoula 1 ,*
}

1 Department of Food Science and Technology, Faculty of Food Sciences, University of West Attica, 12243 Athens, Greece; antondion@uniwa.gr (D.A.); dvougiouklaki@uniwa.gr (D.V.)

2 Department of Animal Science, Agricultural University of Athens, 11855 Athens, Greece; glaliotis@aua.gr

3 Department of Food Science and Human Nutrition, Agricultural University of Athens, 11855 Athens, Greece; ftsironi@aua.gr

4 Department of Veterinary Science, University of Thessaly, 43100 Karditsa, Greece; evalasi@vet.uth.gr

5 Department of Wine, Vine and Beverage Sciences, Faculty of Food Sciences, University of West Attica, 12243 Athens, Greece; arhchatz@uniwa.gr

6 2nd Propaedeutic Department of Internal Medicine, Medical School, National and Kapodistrian University of Athens, "ATTIKON" University Hospital, 12462 Chaidari, Greece; pahalv@gmail.com

* Correspondence: dhouhoula@uniwa.gr

check for updates

Citation: Antonopoulos, D.; Vougiouklaki, D.; Laliotis, G.P.; Tsironi, T.; Valasi, I.; Chatzilazarou,

A.; Halvatsiotis, P.; Houhoula, D. Identification of Polymorphisms of the CSN2 Gene Encoding $\beta$-Casein in Greek Local Breeds of Cattle. Vet. Sci. 2021, 8, 257. https://doi.org/ $10.3390 /$ vetsci 8110257

Academic Editor: Patrick Butaye

Received: 29 August 2021

Accepted: 26 October 2021

Published: 30 October 2021

Publisher's Note: MDPI stays neutral with regard to jurisdictional claims in published maps and institutional affiliations.

\begin{abstract}
This e research focused on the detection and identification of genetic polymorphisms in exon 7 of the $\beta$-casein CSN2 gene in blood samples from Greek Holstein cows and from local breeds of cattle, such as Vrachykeratiki, Katerinis, and Sykias. For this purpose, DNA was isolated from 780 blood samples obtained from Greek Holstein cows, 86 from three local breeds of cattle, namely Brachyceros, Katerinis, and Sykias, and 14 from Greek buffalo. The desired region of exon 7 was amplified by PCR, resulting in 121 and 251 bp products in bovine and buffalo samples. The PCR product was digested with restriction fragment length polymorphism (RFLP) on agarose gels. The restriction enzymes DdeI and TaqI were used. All of the blood samples had the amplified size. The results showed that $74.4 \%$ of the Greek Holstein cows had the A2A2 $\beta$-casein genotype, the three native breads Vrachykeratiki had $57.7 \%$, and the other two had $100 \%$ of the A2A2 $\beta$-casein. From the 14 Greek buffalo, $100 \%$ had the A2A2 $\beta$-casein.
\end{abstract}

Keywords: $\beta$-casein; b-casomorphin-7; polymorphism; PCR-RFLP

\section{Introduction}

The consumption of cow's milk protein is responsible for causing allergies in many people. An allergy occurs when a person's immune system reacts to milk proteins, considering it 'harmful', and manifests itself in one or more hypersensitivity reactions [1]. The incidence of cow's milk protein allergy (especially $\beta$-lactoglobulin and $\beta$-casein) is estimated to be approximately $10 \%$ worldwide [2]. Milk plays an important role in human nutrition and growth, as it is considered an excellent source for the intake of essential amino acids for humans [3]. Whey proteins, apart from providing amino acids, also contribute to the development of intestinal microflora [4]. Bovine milk proteins are divided into two categories: caseins (as1, as2, beta, kappa), which account for $80 \%$ of the total proteins, and whey proteins, which make up $20 \%$. Beta-casein $(\beta-C N)$ constitutes approximately $35 \%$ of the total casein in cow's milk, has a size of 23,983 kDa, and consists of 209 amino acids in the polypeptide chain. There are 12 variants of $\beta-C N(A 1, A 2, A 3, B, C, D, E, F, G, H 1, H 2$, and I) which are produced in milk, depending on the genotype of each cow [5]. The main types of $\beta-\mathrm{CN}$ are $\mathrm{A} 1$ and $\mathrm{A} 2$. According to the literature, the production of $\mathrm{A} 1 \beta$-casein is the result of a point mutation in the bovine CSN2 gene, resulting in the production of A1 $\beta$-casein instead of A2 $\beta$-casein [6]. The difference between A1 $\beta$-casein and A2 $\beta$-casein is in an amino acid of the polypeptide chain. A2 $\beta$-casein contains proline (CCT) at position 
67, while in A1 $\beta$-casein, this has been replaced by histidine (CAT) [7]. This amino acid replacement affects the proteolysis of the primary protein structure, leading to the cleavage of different peptides. Decomposition of A1 $\beta$-casein leads to the production of an opioid peptide called $\beta$-casomorphine-7 (BCM-7), whereas cleavage of $\mathrm{A} 2$ leads to the production of $\beta$-casomorphine-9 (BCM-9) [3]. BCM-7 is a smaller molecule, which can enter the bloodstream more easily, and has stronger opioid effects. BCM-7 is the substance primarily responsible for gastrointestinal disorders such as bloating, increased gas excretion, and bowel disorders [8].

Currently, three indigenous cattle breeds are mainly bred in Greece, and are considered as threatened with extinction. Two of them, Sykia and Katerini originated from the Primigenius Steppe breed, while the third one, Brachyceros, originated from Bos taurus Brachyceros. Four more autochthonous Greek breeds have been considered as officially extinct (Tinos, Andros, Chios, Kerkyra), one breed as endangered (Kea), while more than 10 unidentified breeds or populations have been reported (Prespa, Rodopi, Crete, Kastelorizo, Nissyros, Lipsi, Agathonissi, Lesvos, Acheloos, Mani). These autochthonous cattle are mainly bred in semi-mountainous and mountainous areas or islands, in free-range farming systems, under poor feeding and lack of management $[9,10]$. The objective of this study was to identify the frequency and type of genetic polymorphisms in exon 7 of the $\beta$-casein CSN2 gene in cows of Holstein, Brachyceros, Katerini, and Sykia breeds, as well as, in Greek buffalo of Greek farms. The results of this study may aid the selection of cattle based on milk quality traits.

\section{Materials and Methods}

\subsection{Experimental Animals and Farms}

2.1.1. Institutional Animal Care and Use Committee (IACUC)

Animal blood sampling was based on the 2010/63 EU guidelines of European Community and Council on the Protection of Animals used for Scientific Purposes; according to Directive Article 1, Paragraph 5, Element F, 'practices not likely to cause pain, suffering, distress or lasting harm equivalent to, or higher than, that caused by the introduction of a needle in accordance with good veterinary practice' are permitted for experimental purposes.

\subsubsection{Selection and Preparation of Control Samples}

Blood samples from Bos taurus, identified as A2A2, A1A2, and A1A1 (characterized as control samples), were acquired directly from the animals, and were kept at $-18{ }^{\circ} \mathrm{C}$ until the analysis.

\subsubsection{Selection and Preparation of Blood Samples}

During the study period (September 2020 to May 2021), a total of 780 blood samples were collected from Holstein-Friesian cows from different farms in Greece, and 86 samples were obtained from three native breeds of cattle, namely Vrachykeratiki $(n=46)$, Katerinis $(n=20)$, and Sykias $(n=20)$. In addition, 14 samples were collected from Greek buffalo. The blood samples were kept at $-18{ }^{\circ} \mathrm{C}$ until the analysis.

\subsubsection{Genomic DNA Extraction}

DNA was directly extracted from blood samples using an automatic extractor with the Whole Blood Nucleic Acid Extraction Kit, (ZYBIO Company), following the protocol recommended by the supplier. The purity and the quantity of the extracted DNA was evaluated spectrophotometrically by calculating $\mathrm{OD}_{260} / \mathrm{OD}_{280}$ (Epoch spectrophotometer, BioTek, Winooski, VT, USA).

\subsubsection{PCR Amplification and Restriction Fragment Length Polymorphism Detection I}

After checking for DNA/RNA purity, PCR was carried out. The chosen primers amplify a size of $121 \mathrm{bp}$ of the genomic region of exon 7 of CSN2, using $0.6 \mu \mathrm{M}$ primers forward 5'-CCTTCTTTCCAGGATGAACTCCAGG-3' and reverse 5'-GAGTAAGAGGAGGG 
ATGTTTTGTGGGAGGCTCT-3' [11]. PCR was performed in $50 \mu \mathrm{L}$ final volume solution using the Master Mix (Hot Start Promega). The amplification was conducted by a thermal cycler (96-well thermal cycler from Applied Biosystems, Thermo Scientific, Agawam, MA, USA), as follows: an initial denaturation at $95^{\circ} \mathrm{C}$ for $10 \mathrm{~min}$; followed by 40 cycles with the following step-cycle profile: denaturation at $95^{\circ} \mathrm{C}$ for $60 \mathrm{~s}$; annealing at $58^{\circ} \mathrm{C}$ for $60 \mathrm{~s}$; extension at $72{ }^{\circ} \mathrm{C}$ for $60 \mathrm{~s}$, and a final extension at $72{ }^{\circ} \mathrm{C}$ for $10 \mathrm{~min}$.

PCR products were separated in $2 \%$ agarose gels, stained with ethidium bromide $(0.5 \mu \mathrm{g} / \mathrm{mL})$, and documented under UV illumination using MiniBIS Pro device (DNR Bio-Imaging Systems Ltd., Neve Yamin, Israel).

The $121 \mathrm{bp}$ PCR products were digested with $5 \mathrm{U}$ of DdeI (Thermo Scientific) restriction enzyme for $1 \mathrm{~h}$ at $37^{\circ} \mathrm{C}$. Three types of bands were observed- a complete DdeI cut representing homozygous $\mathrm{A} 2 \mathrm{~A} 2$ resulting in two fragments ( 86 and $35 \mathrm{bp}$ ); a partial cut representing heterozygous A1A2 resulting in three fragments of 121, 86, and $35 \mathrm{bp}$; and an uncut $121 \mathrm{bp}$ fragment representing homozygous A1A1 (Figure 1).

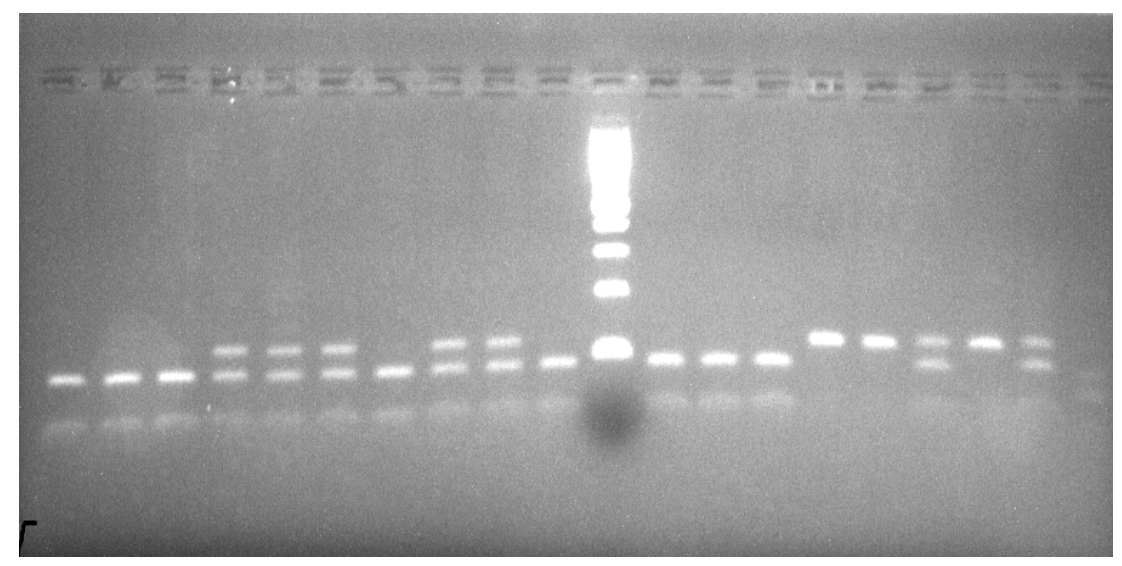

Figure 1. Results of PCR-RFLP analysis for CSN2 gene by DdeI on 3\% agarose gel. Lanes 1-3,7,10, 12-14 genotype A2A2 (86 and 35 bp), Lanes 4-6,8,9,17,19 genotype A1A2 (121, 86 and 35 bp), Lanes 15,16,18 genotype A1A1 (121 bp), Lane 11 Ladder 100 bp, and Lane 20 Negative control.

\subsubsection{PCR Amplification and Restriction Fragment Length Polymorphism Detection II}

After checking for DNA/RNA purity, PCR was carried out. The chosen primers amplify a size of $251 \mathrm{bp}$ in the genomic region of exon 7 of CSN2 using $0.6 \mu \mathrm{M} \mu \mathrm{L}$ of primers forward $5^{\prime}$-GAGTCGACTGCAGATTTTCAACATCAGTGAGAGTCAGGCCCTG$3^{\prime}$ and reverse $5^{\prime}$-CCTGCAGAATTCTAGTCTATCCCTTCCCTGGGC CCATCG-3'. PCR was performed in $50 \mu \mathrm{L}$ final volume solution using the Master Mix (Hot Start Promega). The amplification was conducted by a thermal cycler (96-well thermal cycler from Applied Biosystems, Singapore), as follows: an initial denaturation at $95^{\circ} \mathrm{C}$ for $10 \mathrm{~min} ; 40$ cycles with the following step-cycle profile: denaturation at $95^{\circ} \mathrm{C}$ for $60 \mathrm{~s}$; annealing at $65^{\circ} \mathrm{C}$ for $60 \mathrm{~s}$; extension at $72{ }^{\circ} \mathrm{C}$ for $60 \mathrm{~s}$; and a final extension at $72{ }^{\circ} \mathrm{C}$ for $10 \mathrm{~min}$.

PCR products were separated in $2 \%$ agarose gels, stained with ethidium bromide $(0.5 \mu \mathrm{g} / \mathrm{mL})$, and documented under UV illumination using MiniBIS Pro device (DNR Bio-Imaging Systems Ltd., Neve Yamin, Israel).

The $251 \mathrm{bp}$ PCR products were digested with $5 \mathrm{U}$ of TaqI (Thermo Scientific, Agawam, MA, USA) restriction enzyme for $1 \mathrm{~h}$ at $65^{\circ} \mathrm{C}$. Three types of bands were observed- a complete TaqI cut representing homozygous A1A1 resulting in two fragments (213 and $38 \mathrm{bp}$ ); a partial cut representing heterozygous A1A2 resulting in three fragments of 251, 213, and $38 \mathrm{bp}$; and an uncut $251 \mathrm{bp}$ fragment representing homozygous A2A2.

\subsection{Statistical Analysis}

Analysis of variance (ANOVA) at a significance level of $95 \%(p<0.05)$ was used for the evaluation of differences between the observed allele frequencies (STATISTICA 
7.0; StatSoft Inc., Tulsa, OK, USA). The allele frequencies were in accordance with the Hardy-Weinberg equilibrium.

\section{Results}

Genomic DNA was isolated from blood samples of Holstein-Friesian cows $(n=780)$ and three native breeds of cattle, Vrachykeratiki $(n=46)$, Katerinis $(n=20)$, and Sykias $(n=20)$, as well as the Greek buffalo $(n=14)$. The extracted DNA was checked for its concentration and purity by photometry. All samples had a concentration of 70-100 ng/ $\mu \mathrm{L}$ and a purity of $1.6-1.9 \mathrm{ng} / \mu \mathrm{L}$. As for the exon 7 of CSN2 polymorphism, it was shown that the A2 allele occurs with a frequency of $74.4 \%$ and $58.7 \%$ in Holstein-Friesian cows and Vrachykeratiki, respectively. The A1 allele frequency was 25.6 and $30.4 \%$, respectively. In Katerinis, Sykias, and the Greek buffalo, the A2 allele occurred with a frequency of $100 \%$. In the samples that originated from the Holstein-Friesian breed, $52.2 \%$ of them were homozygous for the A2 allele, and 3.3\% were homozygous for the A1 allele, while the rest $(44.5 \%)$ were heterozygous. For Vrachykeratiki breed, the homozygous A2 genotype frequency was $39.1 \%$, while the A1A1 genotype was not observed. Heterozygous genotypes had a frequency of $60.9 \%$ (Table 1). The other breeds (Sykias) were $100 \%$ homozygous for the A2 allele. There were statistically significant differences between the allele frequency of breeds $(p<0.05)$.

Table 1. Gene and genotype frequency of $\beta$-casein gene.

\begin{tabular}{|c|c|c|c|c|c|c|}
\hline \multirow[t]{2}{*}{ Breeds } & \multirow[t]{2}{*}{$\begin{array}{c}\text { Total No. of } \\
\text { Samples }\end{array}$} & \multicolumn{3}{|c|}{ Genotype Frequency } & \multicolumn{2}{|c|}{ Allele Frequency } \\
\hline & & A1A1 & A1A2 & $\mathrm{A} 2 \mathrm{~A} 2$ & A1 & A2 \\
\hline $\begin{array}{l}\text { Holstein- } \\
\text { Friesian }\end{array}$ & 780 & $\begin{array}{c}(n=26) \\
3.3 \%\end{array}$ & $\begin{array}{c}(n=347) \\
44.5 \%\end{array}$ & $\begin{array}{c}(n=407) \\
52.2 \%\end{array}$ & $25.6 \%$ & $74.4 \%$ \\
\hline Vrachykeratiki & 46 & $\begin{array}{c}(n=0) \\
0 \%\end{array}$ & $\begin{array}{c}(n=28) \\
60.9 \%\end{array}$ & $\begin{array}{l}(n=18) \\
39.1 \%\end{array}$ & $30.4 \%$ & $58.7 \%$ \\
\hline Katerinis & 20 & $\begin{array}{c}(n=0) \\
0 \%\end{array}$ & $\begin{array}{c}(n=0) \\
0 \%\end{array}$ & $\begin{array}{c}(n=20) \\
100 \%\end{array}$ & $0 \%$ & $100 \%$ \\
\hline Sykias & 20 & $\begin{array}{c}(n=0) \\
0 \%\end{array}$ & $\begin{array}{c}(n=0) \\
0 \%\end{array}$ & $\begin{array}{c}(n=20) \\
100 \%\end{array}$ & $0 \%$ & $100 \%$ \\
\hline Greek buffalo & 14 & $\begin{array}{c}(n=0) \\
0 \%\end{array}$ & $\begin{array}{c}(n=0) \\
0 \%\end{array}$ & $\begin{array}{c}(n=14) \\
100 \%\end{array}$ & $0 \%$ & $100 \%$ \\
\hline
\end{tabular}

\section{Discussion}

Local bovine breeds can represent a valuable source of genes for selecting certain traits. To our knowledge, the genetic polymorphism of $\beta$-casein in cows, indigenous and foreign, that are bred in Greece has not been studied so far.

Improving the knowledge of the genetic diversity within and among local breeds is considered an important issue for enhancing their efficient use for sustainable animal farming in a harsh and less intensified environment, and for implementing further conservation programs $[12,13]$. As these local breeds are usually unselected and show high adaptability to their local environment, their genetic pool represents a valuable source of genes that may lead to products of high quality [14]. Although local cattle breeds in Greece are considered dual purpose, they are mainly bred for meat purposes rather than for milk production, due to poor infrastructure and supplementary feeding, which lead to a high production cost. Among them, the Vrachykeratiki breed represent the most known local breed, and belongs to the group of Illyrian Brachyceros cattle (Bos taurus brachyceros). Katerini and Sykia are two Greek cattle breeds under the threat of extinction that belong to the steppe type of cattle, sharing many similarities with Podolian cattle breeds. Another indigenous bovine breed is the Greek buffalo, which is also under the risk of extinction. The Greek buffalo, which belongs to Murrah type of river buffalo, originates from the Asian buffalo, and is 
mainly bred for milk and meat. Like all local breeds, they exhibit great adaptability to harsh climate and wetlands, long productive life, low maintenance needs, and production of high-quality products $[9,14-16]$. Investigating their genetic pool to identify polymorphisms that are linked to the production of final products of high-quality traits or traits focusing on the contemporary human needs (i.e., low fat content, enriched in $\omega 3$ fatty acids, absence of allergens etc.) is of utmost importance. To our knowledge, the genetic polymorphism of $\beta$-casein in cosmopolitan, and especially local bovine, breeds that are bred in Greece has not been thoroughly studied so far. Thus, herein we report the genotyping results of the $\beta$-casein locus (CSN2 gene) in five Greek bovine local breeds and one cosmopolitan breed (Holstein-Friesian) in Greece.

The observed allelic frequencies in the Holstein-Friesian samples are comparable to the respective data in previously reported studies, where a higher frequency of the A2 allele was observed with values ranging from 0.632 to 0.675 , similarly to the present study [17-20].

Another finding emerging from the present study is that A2 allele dominated in the analyzed local bovine breeds, which is in accordance with previous reported studies. Baranyi et al. (1993) reported the high presence of A2 allele of the CSN2 gene in the Hungarian Gray cattle $(\mathrm{pA} 2=0.75)$. The same trend was also observed for Balkan local breeds such as Busa cattle, Slavonian-Syrmian Podolian cattle, and Istrian cattle [20].

\section{Conclusions}

The results of our study indicate that the $\beta$-casein allelic frequencies in the HolsteinFriesian samples were similar to the respective values reported in relevant studies from different geographical regions, while a higher frequency of the A2 allele was observed, with values ranging between 0.632 and 0.675 . The A2 allele dominated in the local Greek bovine breeds.

Author Contributions: Conceptualization, D.H.; methodology, D.A. and D.V.; formal analysis, D.A. and D.V.; writing — original draft preparation, D.A. and D.V.; writing—review and editing, G.P.L., T.T., I.V., A.C., P.H. and D.H.; supervision, D.H. All authors have read and agreed to the published version of the manuscript.

Funding: This research received no external funding.

Institutional Review Board Statement: Ethical review and approval were waived for this study, because participation to the research was on a voluntary basis, no identification was required other than important production parameters which may correlate with results of the study, farmers provided their informed consent to participation in the survey and only blood samples from animals were collected, with the aim to detect and identify potential genetic polymorphisms.

Informed Consent Statement: Farmers provided their informed consent to participation in the survey.

Data Availability Statement: The data presented in this study are available in the manuscript.

Conflicts of Interest: The authors declare no conflict of interest.

\section{References}

1. Monaci, L.; Anklam, A.; Tregoat, V. Milk allergens, their characteristics and their detection in food: A review. Aust. J. Dairy Technol. 2007, 62, 62-71. [CrossRef]

2. Miluchová, M.; Gábor, M.; Trakovická, A. Analysis of Beta-Casein Gene (CSN2) Polymorphism in Different Breeds of Cattle. Sci. Pap. Anim. Sci. Biotechnol. 2014, 47, 56-59.

3. Massella, E.; Piva, S.; Giacometti, F.; Liuzzo, G.; Zambrini, A.V.; Serraino, A. Evaluation of bovine beta casein polymorphism in two dairy farms located in northern Italy. Ital. J. Food Saf. 2017, 6, 131-133. [CrossRef] [PubMed]

4. Kanwar, J.R.; Kanwar, R.K.; Sun, X.; Punj, V.; Matta, H.; Morley, S.M.; Parrat, A.; Puri, M.; Sehgal, R. Molecular and Biotechnological Advances in Milk Proteins in Relation to Human Health. Curr. Protein Pept. Sci. 2009, 10, 308-338. [CrossRef] [PubMed]

5. Sodhi, M.; Kataria, R.S.; Niranjan, S.K.; Verma, P.; Swami, S.K.; Mukesh, M. Sequence 38 Characterisation and Genotyping of Allelic Variants of Beta Casein Gene Establishes Native Cattle of Ladakh to be a Natural Resource for A2 Milk. Def. Lif. Sci. J. 2018, 3, 177. [CrossRef] 
6. Miluchová, M.; Trakovická, A.; Gábor, M. Analysis Polymorphism of Beta Casein of Slovak Pinzgau Cattle by Pcr-Rflp for Allels A1 and A2. Sci. Pap. Anim. Sci. Biotechnol. 2009, 42, 288-292.

7. Kumar, A.; Singh, R.V.; Chauhan, A.; Ilayakumar, K.; Kumar, S.; Kumar, A.; Sonwane, A.; Kumar, S.; Panigrahi, M.; Bhushan, B. Genetic association analysis reveals significant effect of $\beta$-casein A1/A2 loci on production \& reproduction traits in Frieswal crossbred cows. Biol. Rhythm Res. 2019, 51, 1259-1272. [CrossRef]

8. Woodford, K.B. A2 milk, farmer decisions, and risk management. In Proceedings of the 16th International Farm Management Congress: Peer Reviewed Papers; International Farm Management Association: Bristol, UK, 2007; pp. 641-648. Available online: http:/ / researcharchive.lincoln.ac.nz/dspace/handle/10182/417 (accessed on 25 June 2021).

9. Georgoudis, A.; Ligda, C.; Karkavelia, E.; Kotsaftiki, A.; Mizeli, C. Autochthonous Farm Animal Breeds of Greece. Greek Focal Point Manag. Anim. Genet. Resour. 2011, 49, 107.

10. Bizelis, I. Current Situation of Autochthonous Breeds in Greece. 2015. Available online: https://www.save-foundation.net/ images/konferenzen/2015/Iosif_Bizelis_Amaltheia.pdf (accessed on 2 July 2021).

11. Saran, M.; Gurao, A.; Joshi, R.K.; Kashyap, S.K. Prevalence of the BETA case in variants among THARPARKAR, Rathi, sahiwal, Kankrej and cross breed and its influence under selective pressure. Int. J. Curr. Microbiol. Appl. Sci. 2019, 8, 1842-1848. [CrossRef]

12. Rubino, G.; Pieragostini, E.; Caroli, A.; Petazzi, F. Quadro ematologico e proteico quali indici di diversità tra i bovini allevati in puglia: La razza podolica a confronto con le razze cosmopolite da latte. In Taurus Speciale; Anno XIX-Numero 6-Novembre/Dicembre 2007 ANABIC; Associazione Nazionale Allevatori Bovini Italiani da Carne: Perugia, Italy, 2007.

13. Karatosidi, D.; Marsico, G.; Ligda, C.; Tarricone, S. Assessment of the meat quality of Italian Podolian and Greek Katerini cattle. Anim. Genet. Resour. 2012, 53, 141-146. [CrossRef]

14. Georgoudis, A.G.; Ligd, C.; Boyazoglu, J. Population characteristics of water buffaloes in Greek wetlands. Anim. Genet. Resour. 1994, 14, 83-95. [CrossRef]

15. Georgoudis, A.G.; Papanastasis, V.P.; Boyazoglu, J.G. Use of water buffalo for the environmental conservation of waterlandReview. Asian-Australas. J. Anim. Sci. 1999, 12, 1324-1331. [CrossRef]

16. Groeneveld, L.F.; Lenstra, J.A.; Eding, H.; Toro, M.A.; Scherf, B.; Pilling, D.; Negrini, R.; Finlay, E.K.; Jianlin, H.; Groeneveld, E.; et al. Genetic diversity in farm animals-A review. Anim. Genet. 2010, 41, 6-31. [CrossRef] [PubMed]

17. Flori, L.; Moazami-Goudarzi, K.; Alary, V.; Araba, A.; Boujenane, I.; Boushaba, N.; Casabianca, F.; Casu, S.; Ciampolini, R.; Coeur D'Acier, A.; et al. A genomic map of climate adaptation in Mediterranean cattle breeds. Mol. Ecol. 2019, 28, 1009-1029. [CrossRef] [PubMed]

18. Çardak, A.D. Effects of genetic variants in milk protein on yield and composition of milk from Holstein-Friesian and Simmentaler cows. S. Afr. J. Anim. Sci. 2005, 35, 41-47. [CrossRef]

19. Lin, C.Y.; McAllister, A.J.; Ng-Kwai-Hanh, K.F.; Hayes, J.F. Effects of milk protein loci on first lactation production in dairy cattle. J. Dairy Sci. 1986, 69, 704-712. [CrossRef]

20. Ivanković, A.; Pećina, M.; Ramlja, J.; PašićGenetic, V. Ppolymorphism and effect on milk production of CSN2 gene in conventional and local cattle breeds in Croatia. Mljekarstvo 2021, 71, 3-12. [CrossRef] 